\title{
Study of Market Facilities in the Revitalization Project of Klewer Market
}

\section{Yulia Pratiwi ${ }^{1}$, Fadhilah Rusmiati ${ }^{2}$}

\author{
1 Department of Architecture, Islamic University of Indonesia, Yogyakarta \\ 2 Department of Architecture, Lampung University
}

\author{
Article History \\ Received : 17 October 2017 \\ Accepted : 17 November 2017 \\ Published : 01 April 2018
}

\begin{abstract}
Klewer Market is the largest clothing, textile, garment market in Central Java. Klewer Market was established in 1970 and in 2014 there was a fire so that in 2015 the Government of Surakarta City revitalized Klewer Market. In April 2017, Klewer Market has been revitalized and inaugurated. The purpose of this study is to understand the general description of the conditions, the completeness of facilities and utilities, and to investigate the improvement in the management of Klewer Market after revitalization. This research uses qualitative descriptive research to find out a general description of Klewer Market conditions after revitalization in terms of physical buildings, facilities, utilities and management. The analytical method uses a comparison of prerevitalization market conditions with post-revitalization market conditions. The conclusion of this study is that Klewer Market post-revitalization has a more modern concept than pre-revitalization and is able to become one of tourist icons in Surakarta City, which already has more adequate facilities, utilities, and management.
\end{abstract}

Keywords: Klewer Market, Revitalization, Facilities.

\section{Research Background}

Traditional markets concern the livelihoods of many peoples, and the majority are poor people. The implication is that traditional markets have a high strategic value in maintaining the balance of regional development and controlling the economy. Along with trading activities, government, cultural and recreational activities develop around the market. The longer activity is more complex and developing, than a city grows (Bintarto, 1977). Whereas Max Weber looked at a place that was a city if the residents were mostly able to meet their needs through the local market (Daldjoeni, 1998). The market does not always appear by itself or made intentionally. This kind of market is made usually due to the desire of local authorities to meet the needs of the local population. The emergence of markets in royal centers such as Kotagede, Kerta, Plered,

Correspondence:Yulia Pratiwi

Department of Architecture, Islamic University of Indonesia, Yogyakarta

E-mail: yulia.pratiwi@uii.ac.id
Kartasura, Surakarta, and Yogyakarta is a real example (Sutjipto, 1970).

Klewer Market is very closely related to the Surakarta Hadiningrat Palace and Surakarta Grand Mosque. It is a traditional market that was established in 1970 in the Gajahan SubDistrict Pasar Kliwon SubDistrict which specializes in the trade of batik, textile, and garment. As the largest textile shopping center in Central Java, Klewer Market is very viable for revitalization. In addition to serving trade in particular textile regionally, the existence of the Klewer Market is also an icon of tourism in Surakarta City. The construction of the new face of Klewer Market is done to increase the competitiveness of Klewer Market with modern trade such as the Mall which is starting to bloom in Surakarta City.

Revitalization of Klewer Market was carried out after the fire caused by an electrical surge on December 27 in 2014 which resulted in losses of up to trillions. The temporary dismissal of this trade activity disrupts the pace of the Surakarta city economy, especially in the trade sector, considering that the trading transac-tions in the 
Klewer market reach almost tens of millions every day. The event was a momentum to provide an opportunity for the city government to improve the quality of buildings along with supporting facilities that matched the service standards and needs of the trader.

There were 1753 official traders and nearly a thousand unofficial traders occupying the market square. The process of improving the quality of the Klewer Market building lasts for three years and uses funds from the Government of Indonesia of Rp 157.8 billion, and the development process is carried out in two stages. The inauguration of Klewer Market was carried out by President Joko Widodo and the Mayor of Surakarta FX. Rudyatmo on April 21, 2017. With the revitalization of Klewer Market especially physically, it is hoped that it can provide more comfortable and modern services that can increase the number of visitors so that the economy of Surakarta City can run well.

\section{The Research Problems}

a. What is the condition of Klewer Market after revitalization?

b. What are the facilities and utilities in the new Klewer Market building?

c. Is there an improvement in management to support the Klewer Market trading activities?

The Research Purposes

a. Provide the general description of the condition of Klewer Market after revitalization

b. Identify the complete facilities and utilities of Klewer Market

c. Identifying the management of Klewer Market in supporting trading activities.

\section{Literarur Review}

According to Minister of Trade Regulation No. 53 of 2008 concerning Guidelines for Arrangement and Development of Traditional Markets, Shopping Centers, and Modern Shops, the understanding of markets is an area to sale the goods with more than one seller, both referred to as shopping centers, traditional markets, shops, malls, plaza, trade center, and other designations. Wiryomartono (1995) states that markets in Java are routine activities where socio economic activities occur and develop. The mar-ket in Javanese urban life is the surrounding community to exchange, sell agricultural production and household industries. In the decades of 1920-1935, on Java, many markets were established by the colonial government. Physical characteristics are characterized by the composition of the iron loses that form the eastwest groove in accordance with solar radiation (Sunoko, 2006).

According to the Surakarta City Regulation Number 1 of 2010 concerning Management and Protection of Traditional Markets, market facilities include the main components and supporting components. The main components of market facilities consist of land, kiosks, stalls, tents, electricity networks, drainage, parking facilities, loading and unloading facilities, religious facilities, management office facilities, toilet facilities and clean water, and security facilities, fire extinguishers (hydrant), sanitation facilities, facilities for people experiencing physical limitations, road access and doors. Supporting components of market facilities are telecommunication networks, advertisement space, warehouses, postal services for recalculating scales and equipment, roads or emergency gates, transportation equipment (stairs,escalators/elevators), integrated service posts, service posts, and green open space.

Market management is still under the management of the market. While market management is not only in the management stage but also in the market protection stage (Surakarta City Mayor Regulation No. 4 of 2011 concerning Management Guidelines and Protection of Traditional Markets). Market management is a concerted effort carried out to organize and foster market presence which includes policies in planning, licensing, structuring, utilization, development, control, maintenance, supervision, guidance, and evaluation as well as law enforcement. Market Protection is an integrated effort to build market resilience that is sustainable and is able to empower the market as a space for economic activity in achieving business prosperity for market communities while paying attention to the sustainability of the business of traders.

\section{Research Method}

Types of research:

This research uses qualitative descriptive 
research to find out a general description of Klewer market conditions after revitalization both in terms of physi-cal buildings and facilities and utilities and management. Descriptive research according to Sanusi (2014) is a research design arranged in order to provide a systematic description of scientific information that comes from the subject or object of research. With the descriptive method, the aspects of the research can be described according to existing conditions in the field.

\section{Research variables:}

According to Sugiyono (2013), the research variable is basically everything in the form of what is determined by the researcher to be studied so that information is obtained about it, then the conclusion is drawn. This research is a qualitative descriptive study so that parameters and benchmarks are needed to facilitate data search and data analysis. Variables, parameters, and benchmarks of the research are described in Table 1 as follows.

\section{Data analysis method}

The method of analyzing data in this study is shown in Table 2.

\section{Result and Discussion}

\section{Overview of Research Location}

Klewer Market, which is the largest textile trade center in Central Java which has been
Surakarta City. This traditional market has been revitalized after the fire incident on December established since 1970. It is the heart of the economy and is one of the tourism icons of 27 , 2014 , due to a surge in electricity. In addition, the condition of the old building made the incident burn all the merchant kiosks to cause losses of up to trillions of rupiah. Instead, the Surakarta City Government built a temporary market that occupied the northern square for two years.

The revitalization process which consists of rebuilding for one and a half years and through two stages of development to spend and the state budget of 157.8 billion. The inauguration of the new face of Klewer Marketwas carried out by President Joko Widodo on April 21, 2017, to coincide with Kartini Day. The new Klewer Market building carries a modern

\begin{tabular}{|c|c|c|}
\hline Data & Method & Output \\
\hline $\begin{array}{l}\text { The Conditions } \\
\text { of Klewer Market }\end{array}$ & $\begin{array}{l}\text { De- } \\
\text { scriptive } \\
\text { Qualita- } \\
\text { tive }\end{array}$ & $\begin{array}{l}\text { Description of the Klew- } \\
\text { er Market conditions af- } \\
\text { ter revitalization }\end{array}$ \\
\hline $\begin{array}{l}\text { The Facilities } \\
\text { and Utilities }\end{array}$ & $\begin{array}{l}\text { De- } \\
\text { scriptive } \\
\text { Qualita- } \\
\text { tive }\end{array}$ & $\begin{array}{l}\text { Identify the facilities and } \\
\text { utilities of Klewer Market }\end{array}$ \\
\hline $\begin{array}{l}\text { Management of } \\
\text { Klewer Market }\end{array}$ & $\begin{array}{l}\text { De- } \\
\text { scriptive } \\
\text { Qualita- } \\
\text { tive }\end{array}$ & $\begin{array}{l}\text { Identify management of } \\
\text { Klewer Market in sup- } \\
\text { porting trading activities }\end{array}$ \\
\hline
\end{tabular}

Table 1 Variables, Parameter, Method, and Re-search Benchmarks

\begin{tabular}{|c|c|c|c|}
\hline Variables & Parameter & Method & Research Benchmarks \\
\hline \multirow{6}{*}{$\begin{array}{l}\text { Revitalization } \\
\text { of Klewer } \\
\text { Market }\end{array}$} & $\begin{array}{l}\text { The Conditions of } \\
\text { Klewer Market }\end{array}$ & \multirow{6}{*}{$\begin{array}{l}\text { Primary Sur- } \\
\text { vey and Sec- } \\
\text { ondary Survey }\end{array}$} & $\begin{array}{l}\text { The implication is that traditional markets have a high strate- } \\
\text { gic value in maintaining the balance of regional development } \\
\text { and controlling the economy. (Bintarto, 1977) }\end{array}$ \\
\hline & $\begin{array}{l}\text { The Facilities and } \\
\text { Utilities }\end{array}$ & & $\begin{array}{l}\text { - Market offices, road access, stairs, escalators, elevators, } \\
\text { toilets, electricity networks, clean water, drainage, telecom- } \\
\text { munications networks, sanitation facilities, parking, prayer } \\
\text { rooms, loading and unloading, security posts, fire engines } \\
\text { (hydrant), roads and emergency doors warehouses. }\end{array}$ \\
\hline & & & $\begin{array}{l}\text { - Facilities for Disabilities People } \\
\text { - Green open space }\end{array}$ \\
\hline & & & $\begin{array}{l}\text { Source: Regulation from Surakarta City Government, Num- } \\
\text { ber 1, } 2010 \text { about Management and Protection of Traditional } \\
\text { Markets }\end{array}$ \\
\hline & $\begin{array}{l}\text { Management of } \\
\text { Klewer Market }\end{array}$ & & $\begin{array}{l}\text { - Market management: policies for planning, } \\
\text { licensing, structuring, utilization, development, } \\
\text { control, maintenance, supervision, guidance, and } \\
\text { evaluation as well as law enforcement. }\end{array}$ \\
\hline & & & $\begin{array}{l}\text { - Market Protection: builds market resilience that is } \\
\text { sustainable and is able to empower the market as } \\
\text { a space for economic activity }\end{array}$ \\
\hline
\end{tabular}


Study of Market Facilities in the Market Revitalization Project of Klewer Market

Yulia Pratiwi, Fadhilah Rusmiati

The new Klewer Market building carries a modern concept both in terms of physical building and in terms of its management. This modern concept was chosen by the city government as a step to maintain the existence of Klewer Market amidst the construction of malls in Surakarta City. Although modern, the Klewer Market with this modern concept still retains the characteristics of traditional markets with a tradition of bargaining and trading local commodities originating from local businesses in Surakarta City. The following are research loca-tions which can be seen in Figure 1.

Figure 1. Research Location

Source: http://indonesia-peta.blogspot.co.id with modification, 2019

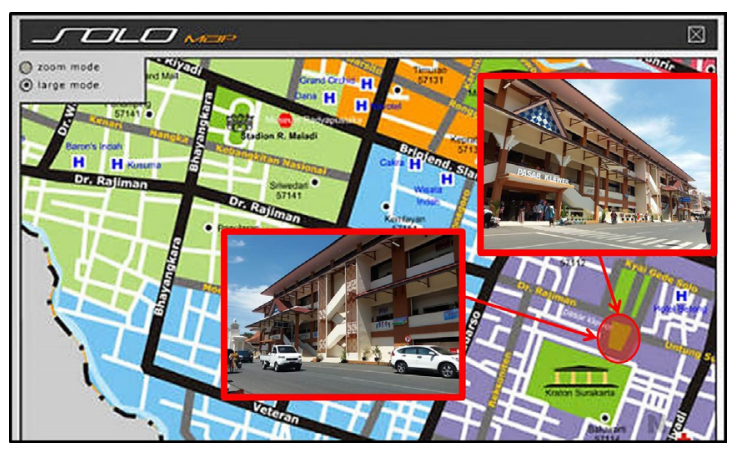

\section{Identification of Facilities and Utilities of Klewer Market}

Revitalization of the Klewer Market building with a modern concept is certainly supported by complete facilities. Based on online news, the Surakarta City Government has planned to increase the klewer market class to class $1 \mathrm{~A}$, which is the highest class in the market standard based on Mayor Regulation number 4 of 2011 concerning Guidelines for Regional Regulation Number 1 of 2010 concerning Guidelines for Management and Protection of Traditional Markets (source: Wardhani, 2017). By conducting field observations followed by documentation of the research, it can be identified the complete facilities and utilities of Klewer Market.

\section{a. Market Office and Security Post}

The market office of the new building of Klewer Market is located on the basement floor, precisely in the parking area (Figure 2). Previously the market office was on the top floor, but with consideration for the convenience of traders so that the market office area is on the basement floor. The security post is on the basement floor and besides that, it also places officers on patrol on each floor.

According to the Surakarta City Regulation Number 1 (2010) concerning Management and Protection of Traditional Markets, market offices and security posts of Klewer Market are already in line with quality standards and needs.

Figure 2. Office of Klewer Market

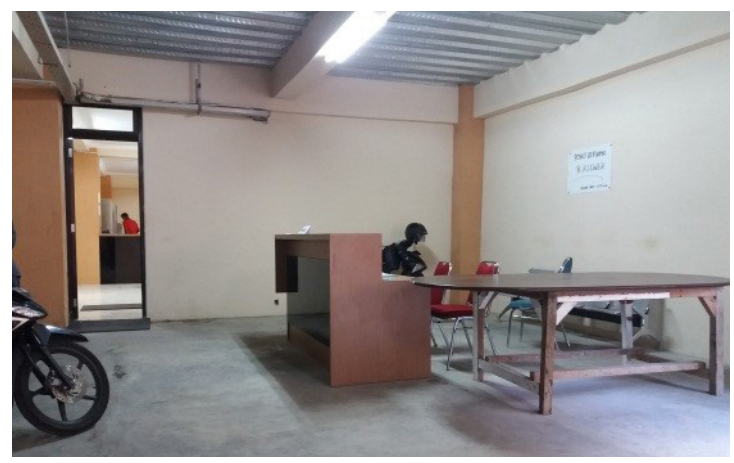

b. Access of roads, stairs, escalators, elevators (accessibility)

For accessibility in the revitalization building, three accesses are available, namely the ladder (Figure 3 ) is located at three points precisely in the middle of the building, the escalator (Figure 4 ) is at one point in the north and the elevator (Figure 5) is placed at two points to the west and east of the market building. The availability of these three accesses is to support the modern concept in the new Klewer Market building.

According to the Surakarta City Regulation Number 1 (2010) concerning Management and Protection of Traditional Markets, the access of roads, stairs, escalators, and elevators are already in line with quality standards and needs.

\section{Figure 3. Ladders}

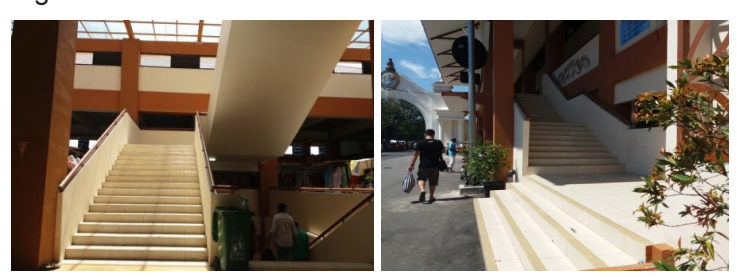


Journal of Architectural Research and Design Studies Volume 1 Number 2 October 2018

21

Figure 4.Escalators

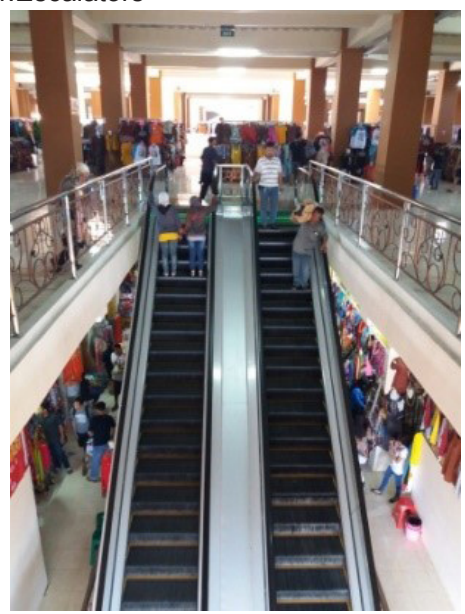

Figure 5. Elevator

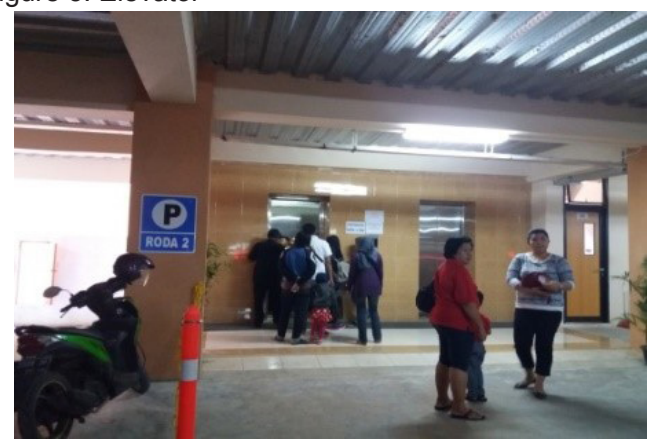

c. Toilet Facilities

Toilet facility (Figure 6) is spread out every 4 points each on the basement floor, semi basement floor, 1st floor and 2nd floor.

According to the Surakarta City Regulation Number 1 (2010) concerning Management and Protection of Traditional Markets, toilets facilities of Klewer Market are already in line with quality standards and needs.

Figure 6. Toilets
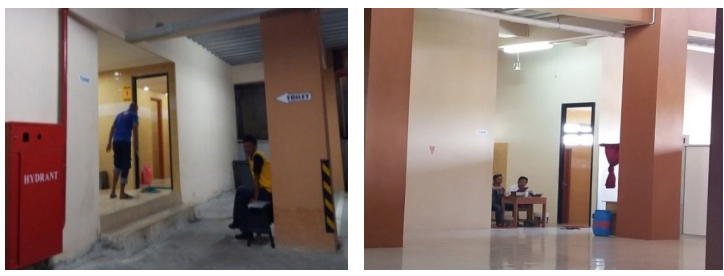

d. Electricity and Telecommunication Network

The electricity network in this building (Figure 7 ) is done with a closed system. The placement is united with a telecommunications network that connects to all available kiosks, especially for kiosks that have a Placement Rights Letter.
According to the Surakarta City Regulation Number 1 (2010), electricity and telecommunication networks of Klewer Market are already in line with quality standards and needs.

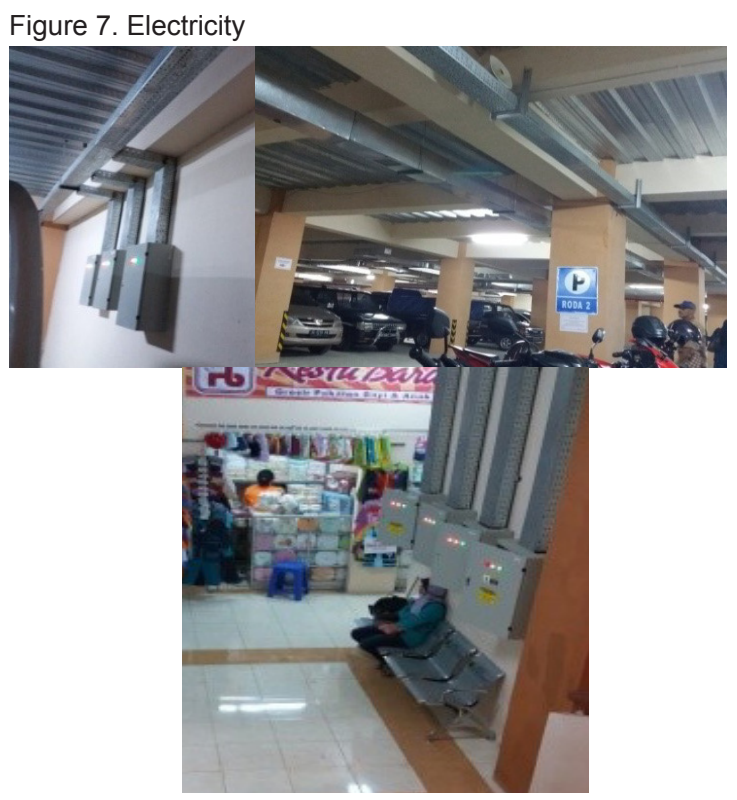

\section{e. Clean water and drainage channels}

The clean water network system is closed (Figure 8), but for drainage, it is still open (Figure 9). Thus it is necessary to renew the drainage system to be closed so as not to disturb the comfort of both visitors and traders.

Figure 8. Clean Water Utility

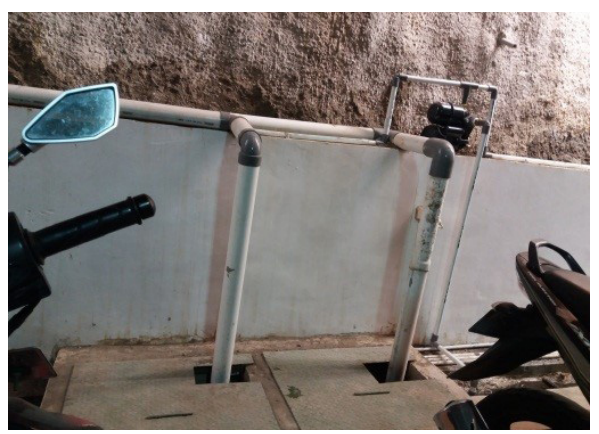

Figure 9. Drainage Utility

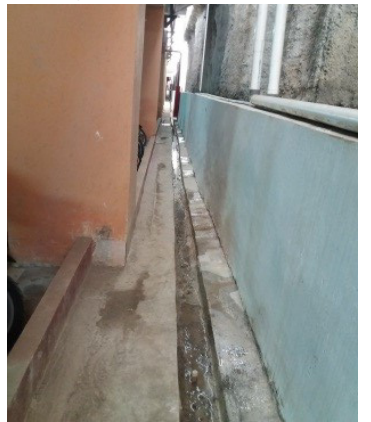


Study of Market Facilities in the Market Revitalization Project of Klewer Market

Yulia Pratiwi, Fadhilah Rusmiati

According to the Surakarta City Regulation Number 1 (2010), clean water utility and drainage utility of Klewer Market are already in line with quality stand-ards and needs.

\section{f. Cleanliness Facilities}

Cleaning facilities on each floor are provided while trash can for communal waste in the form of garbage bins placed south of the market building. Cleaning facilities are shown in Figure 10

Figure 10. Cleanliness Facilities

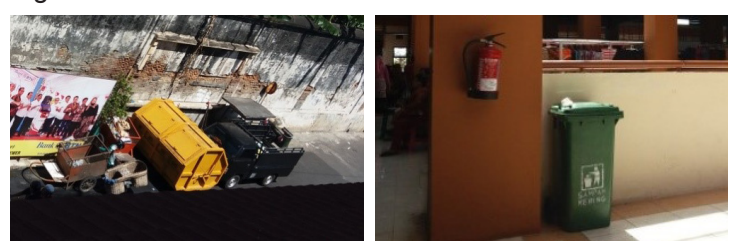

According to the Surakarta City Regulation Number 1 (2010), Cleanliness Facilities of Klewer Market are already in line with quality standards and needs.

\section{g. Parking Facilities}

Parking facilities as a whole are directed to use the basement parking area. This is done to reduce congestion along $\mathrm{Dr}$ Radjiman Street (Klewer Market segment). Parking fees use a progressive tariff system while applying parking restrictions for vehicles belonging to employees and traders which are only limited to one third of the basement parking lot. While the rest is devoted to visitors. Recorded basement parking lots can accommodate 145 cars (Figure 11) and 600 motorcycles (Figure 12). Progressive parking rates apply for IDR 2,000 for cars and IDR 1,000 for motorbikes and this rate will increase by two hours. This rule is also followed by a ban for traders to use the basement floor for a place to sell.

Figure 11. Car Parking lots

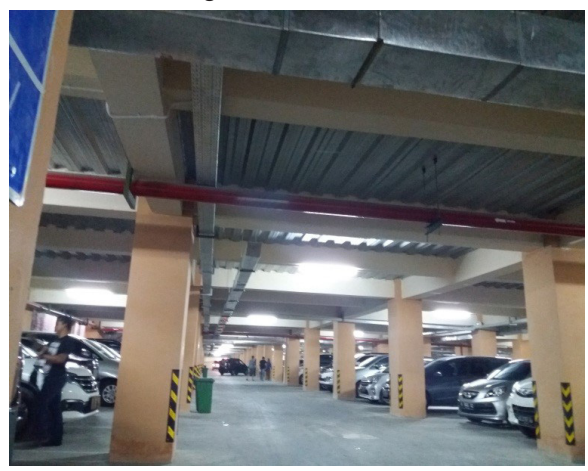

Figure 12. Motorcycles Parking Facilities

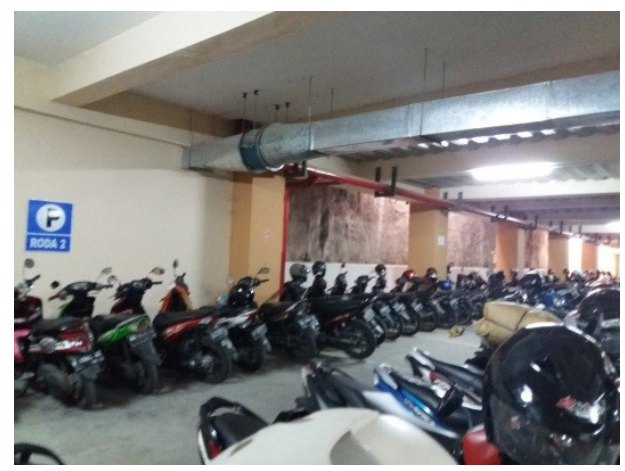

According to the Surakarta City Regulation Number 1 (2010), parking lots of Klewer Market are already in line with quality standards and needs.

\section{h. Mosque}

The mosque is on the 2nd floor where it is the top floor and is equipped with a lactation room beside it. The mosque is shown in Figure 13.

Figure 13. Mosque

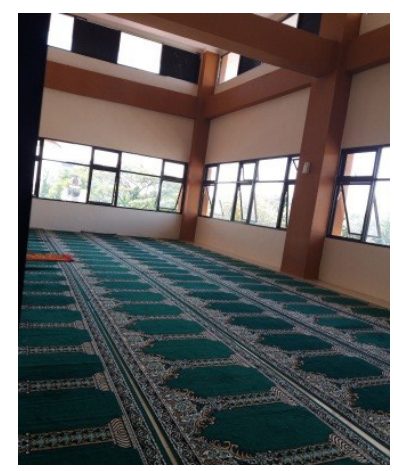

According to the Surakarta City Regulation Number 1 (2010), Mosque of Klewer Market are already in line with quality standards and needs.

\section{i. Loading and Unloading facilities}

For loading and unloading in the new Klewer Market building is done manually with stairs and escalators. Meanwhile, according to the officer the loading and unloading process was carried out on the side of the market building. Loading and unloading facilities are shown in Figure 14.

According to the Surakarta City Regulation Number 1 (2010), loading and unloading facilities of Klewer Market are already in line with quality standards and needs. 
Figure 14. Loading and unloading facilities

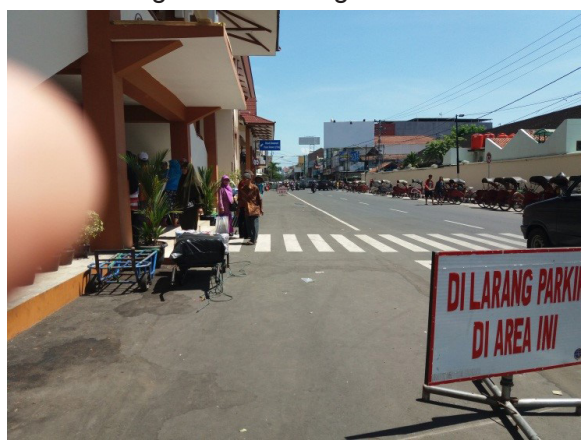

\section{j. Hydrant}

Placement of hydrant and fire extinguishers exist on each floor (Figure 15 and Figure 16). In addition, this building also uses a water sprinkler system (Figure 17) that is used with an alarm sensor. This was done to avoid similar incidents in 2014.
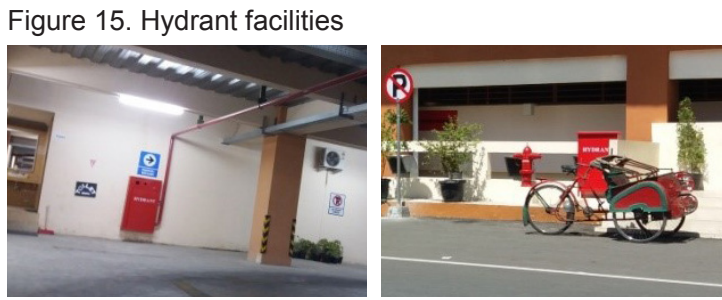

Figure 16. Fire extinguishers

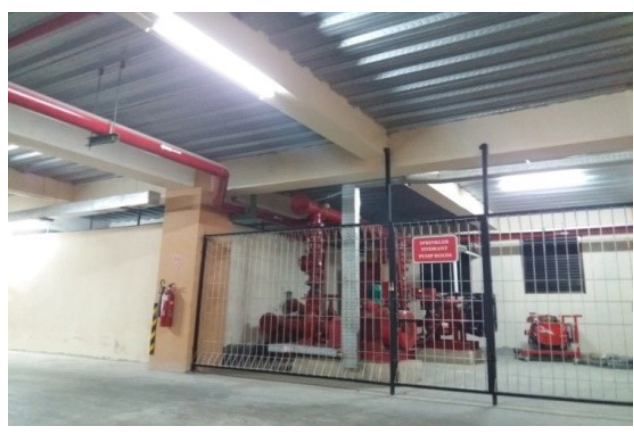

Figure 17. Water Sprinkler

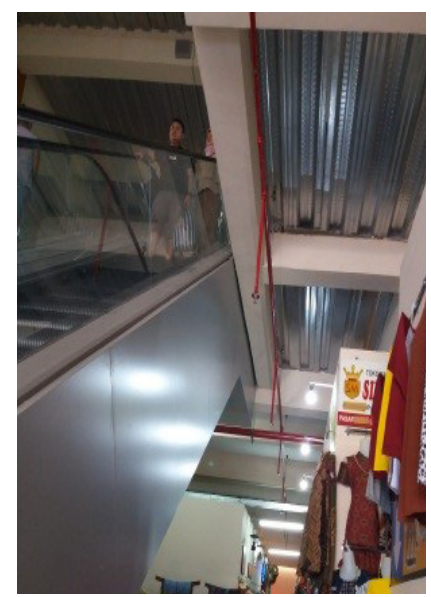

According to the Surakarta City Regulation Number 1 (2010), hydrant facilities of Klewer Market are al-ready in line with quality standards and needs.

\section{k. Emergency Roads and Emergency Doors}

Emergency doors are placed at several points di-rectly connected with the main door of Klewer Mar-ket. The emergency road is shown in Figure 18.

Figure 18. Emergency Road

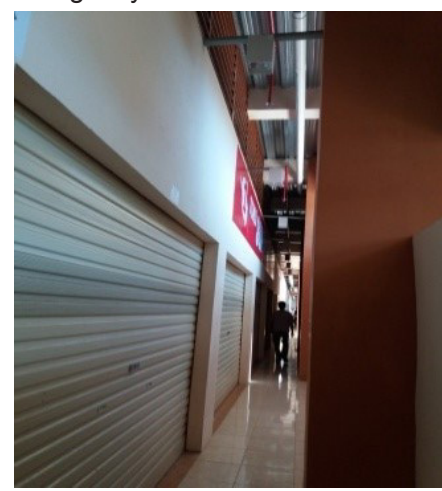

\section{k. Warehouse}

Warehousing facilities are located in the basement area near the parking area. For specifics, each floor does not have a special warehouse. This is because each trader keeps a stock of merchandise at each kiosk.

\section{Means for People Experiencing Physical Limitations}

To meet the needs of people with disabilities using elevators so that other disabled facilities do not meet. Based on a brief interview with market management officers, the government plans to add facili-ties for people with special needs or disabilities.

\section{m. Green Open Space and Public Space}

For green open space until now it has not been ful-filled, but for public space available on the 2nd floor which is the top floor (Figure 19). On the top floor, this is a special zone for traders who were previously in the courtyard of Klewer Market. On this floor there is also a prayer room and a lactation room. In addi-tion, there is still room for other activities such as gathering and relaxing. 
Figure 19. Public Space

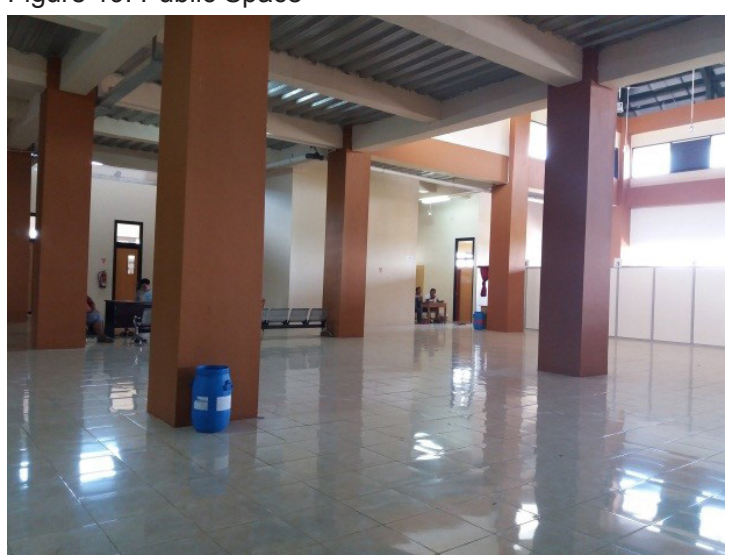

According to the Surakarta City Regulation Number 1 (2010), open space facilities of Klewer Market are already in line with quality standards and needs.

Identification of Klewer Market Management

The impact caused by revitalization is that in terms of buildings to be nicer, cleaner, no longer muddy if it rains, but in terms of income, not all markets become crowded after being revitalized (Anggraini et al, 2017). To anticipate a decrease in income, the Surakarta City government makes integrated mar-ket management.

The governance system is one of the most im-portant elements in the procurement of a good mar-ket. The market should be managed with integrated management where all aspects of market management are integrated into one system. The integration of the market management system is a condition for the realization of professional management. The market cannot be managed separately from one part to another. Market managers must be integrated with market financial management, especially in terms of parking revenue management, planning, operational financing, and maintenance.

In terms of parking management, human resources must be integrated with labor requirements in each part and integrated with market financial management in payroll and cost requirements for employee development. Hygiene management in order to realize a clean market will not succeed without cooperation between the cleaning department. with the HR department and the finance department, especially in the supply of labor needed in financing operational hygiene. Integrated market management is the key to create of market management professionalism.

For withdrawal of levies will be done by electronic systems or what is called as e-retribution by involving third parties, namely the Bank Tabungan Negara (BTN). However, the planned withdrawal of levies will only begin in June 2017. The application of e-retribution is done to suppress leakage and irregularities, thus the potential for Regional Original Income is more optimal and measurable. In the future, traders who have participated in the e-retribution program can obtain micro KPR loans from BTN.

\section{Conclusion}

Based on the results of the discussion in the previ-ous chapter it can be concluded that the revitalization of Klewer Market is a traditional market that has a modern concept and is able to become a tourist icon of Surakarta City. Some of the city's breakthrough efforts in revitalizing Klewer Market include the following.

a. The addition of facilities that characterize modern trade buildings such as the use of escalators and elevators makes it easy for visitors to access. In addition, the use of a water sprinkler system as a fire extinguisher to prevent similar events in the previous year

b. Applying management with a new system to oversee the Klewer Market trade travel distribution considering the Regional Original Income from the transaction process at Klewer Market is quite large. Some new systems such as the use of progressive parking rates, the application of electronic retribution (e-retribution).

c. For special or disabilities people and goods loading and unloading facilities that are still not well accommodated.

\section{References}

Anggraini, Gita et.al. (2017). Standar Revitalisasi Pasar Tradisional di Indonesia (Studi Kasus Pasar Tradisional di Kota Semarang). Jurnal Karya Teknik Sipil. Volume 6 Nomor 1: 12-22.

Anonim. (2019). http://indonesia-peta.blogspot. 
co.id (diakses pada tanggal Januari 2019).

Bintarto. (1977). Pengantar Geografi Kota. Spring. Yogyakarta.

Daldjoeni, N. (1998). Geografi Kota dan Desa Alumni. Bandung.

Minister of Trade Regulation, Republic of Indone-sia Number 53 in 2008 about Pedoman Penataan Dan Pembinaan Pasar Tradisional, Pusat Per-belanjaan dan Toko Modern.

Regulation of Surakarta City Government, Number 1 in 2010 about Pengelolaan dan Perlindungan Pasar Tradisional.

Regulation of The Surakarta City Mayor, Number 4 in 2011 about Petunjuk Pengelolaan dan Perlindungan Pasar Tradisional.

Sanusi, Anwar. (2014). Metode Penelitian Bisnis. Salemba Empat. Jakarta.

[9] Sugiyono.(2013). Metode Penelitian Kuantitatif Kualitatif dan R \& D. Alfabeta. Bandung.

Sunoko, Kahar. (2006). Perencanaan Pasar Tradisional Menghadapi Tekanan Hypermarket di Perkotaan. FT UNS.

Sutjipto.(1970). Beberapa Tjatatan Tentang Pasar-Pasar di Djawa Tengah (abad 17-18). Buletin Fakultas Sastra dan Kebudayaan UGM. Yogyakar-ta.

Wardhani, Indah Septiyaning. 2017. Ada Lift dan Eskalator, Status Pasar Klewer Solo akan Jadi Kelas 1A Plus. Solopos. com. (https://soloraya.solopos.com/ $\mathrm{read} / 20170403 / 489 / 806852 / a d a-l i f t-d a n-$ eskalator-status-pasar-klewer-solo-akanjadi-kelas-ia-plus diakses pada Maret 2019).

Wiryomartono. (1995). Seni Bangunan dan Seni Bina Kota di Indonesia. Gramedia Pusaka Utama.Jakarta. 